\title{
Abscisic Acid, Calmodulin Response to Short Term and Long Term Salinity and the Relevance to NaCl-induced Antioxidant Defense in Two Mangrove Species
}

\author{
Niya $\mathrm{Li}^{1,2}$, Chunyan $\mathrm{Li}^{1}$, Shaoliang Chen ${ }^{*}{ }^{1,3}$, Yu Chang ${ }^{1}$, Yunxia Zhang ${ }^{1}$, Ruigang Wang ${ }^{1}$, \\ Yong Shi ${ }^{1}$, Xiaojiang Zheng ${ }^{3}$, Eberhard Fritz ${ }^{4}$ and Aloys Hüttermann ${ }^{4}$ \\ ${ }^{I}$ College of Biological Sciences and Technology, Beijing Forestry University, Beijing 100083, P.R. China \\ ${ }^{2}$ Department of Biology, Hainan Normal University, Haikou 571158, P.R. China \\ ${ }^{3}$ Key Laboratory of Biological Resources Protection and Utilization in Hubei Province, Hubei University for \\ Nationalities, Enshi 445000, P.R. China \\ ${ }^{4}$ Büsgen Institute, Forest Botany and Tree Physiology, Georg-August-University of Göttingen, Büsgenweg 2, 37077 \\ Göttingen, Germany
}

\begin{abstract}
In this study we investigated the effects of short term (ST, $24 \mathrm{~h}, 100 \mathrm{mM} \mathrm{NaCl}$ ) and long term (LT) salinity (4 weeks, $\mathrm{NaCl}$ increased weekly from 100 to $400 \mathrm{mM}$ ) on leaf abscisic acid (ABA), calmodulin (CaM) and activity of antioxidant enzymes (superoxide dismutase, SOD; peroxidase, POD) in 1-year-old seedlings of two mangrove species, Kandelia candel and Bruguiera gymnorrhiza. The gas exchange and salt $\left(\mathrm{Na}^{+}\right.$and $\left.\mathrm{Cl}^{-}\right)$accumulation upon a $\mathrm{LT}$ stress were compared between the two species. Results show that stomatal conductance, net photosynthetic rates and unit transpiration rates of the two species were significantly decreased by LT salinity and the inhibitory effects were more pronounced in $K$. candel, especially at high saline conditions. Leaf $\mathrm{Na}^{+}$and $\mathrm{Cl}^{-}$concentrations in both species steadily increased with increasing the period of salt stress, but $K$. candel exhibited a higher capacity for salt exclusion. Malondialdehyde content and membrane permeability did not significantly increase in the two mangroves during the prolonged period of salt exposure. $\mathrm{NaCl}$ up-regulated $\mathrm{ABA}, \mathrm{CaM}$ and activity of $\mathrm{SOD}$ and $\mathrm{POD}$ in the two species, but different trends were observed. (1) Upon a ST stress, leaf ABA in $K$. candel increased rapidly and reached the peaking levels after $4 \mathrm{~h}$, and activity of antioxidant enzymes correspondingly increased to the peaking values after 8 hours of stress. In B. gymnorrhiza leaves, SOD and POD activity exhibited a coincident increase after the initiation of salt exposure and leaf CaM markedly increased after 8 hours. (2) Under a LT salinity, $K$. candel maintained high levels of leaf ABA and POD activity, whereas B. gymnorrhiza retained high CaM levels during the period of stress, and SOD activity was markedly elevated at high salinity $(400 \mathrm{mM} \mathrm{NaCl})$. Therefore, we conclude that the two mangrove species were able to up-regulate the activity of antioxidant enzymes to avoid excess reactive oxygen species and the subsequent oxidative stress despite a $\mathrm{NaCl}$ buildup in salinised plants. The elevation of antioxidant enzymes is likely associated with the saltinduced rise of $\mathrm{ABA}$ and $\mathrm{CaM}$ since the acceleration effect of $\mathrm{NaCl}$ on antioxidant enzymes were inhibited by $\mathrm{ABA}$ synthesis inhibitor, tungstate (sodium form) and CaM inhibitor, trifluoperazine (TFP).
\end{abstract}

Keywords: ABA, Bruguiera gymnorrhiza, CaM, Kandelia candel, leaf, POD, salt stress, SOD, TFP, tungstate (sodium form).

\section{INTRODUCTION}

To alleviate salt-induced oxidative stress, plants detoxify reactive oxygen species (ROS) by up-regulating antioxidant enzymes and producing low molecular antioxidants [1-3]. A correlation between antioxidant capacity and $\mathrm{NaCl}$ tolerance has been widely established in cotton cultivars [4], rice [5], foxtail millet [1], pea [6] and poplars [7,8]. Noteworthy, the role of stress messengers, ABA and $\mathrm{CaM}$ in antioxidant defense in salinised plants has received much attention.

In general, salinity increases biosynthesis and accumulation of $\mathrm{ABA}$, which modulates physiological

*Address correspondence to this author at the College of Biological Sciences and Technology, Beijing Forestry University, Box 162, Beijing 100083, P.R. China; Tel: +86-10-62338129; Fax: +86-10-62336164;

E-mail: Lschen@bjfu.edu.cn reactions in plant response to salinity [9-11]. It has been documented that $\mathrm{ABA}$ induced the expression of antioxidant genes encoding $\mathrm{Cu} / \mathrm{Zn}$-superoxide dismutase $(\mathrm{Cu} / \mathrm{Zn}-\mathrm{SOD})$ [12]. Comparative studies show that a salt-tolerant Populus species, Populus euphratica Oliv. was sensitive to salt stress and the root increased ABA synthesis under lower salinity [13, 14]. Recently, we found that $P$. euphratica plants were able to enhance active oxygen detoxification at an early-stage of salt stress [7], which is presumably associated with its higher capacity to synthesize ABA under saline conditions.

Calmodulin (CaM), a ubiquitous calcium-binding protein, regulates the activity of a variety of enzymes and proteins that conferring salt tolerance. Yoo et al. (2005) found that overexpression a specific calmodulin isoform, Gm-CaM4, in Arabidopsis up-regulated the transcription rate of AtMYB2regulated genes, e.g. the proline synthesis enzyme P5CS1 $(\triangle 1$ pyrroline-5-carboxylate synthetase-1), which confers salt 
tolerance by facilitating proline accumulation [15]. Yang and Poovaiah (2002) demonstrated the role of $\mathrm{CaM}$ in regulating $\mathrm{H}_{2} \mathrm{O}_{2}$ homeostasis, i.e. CaM down-regulated $\mathrm{H}_{2} \mathrm{O}_{2}$ levels in plants by stimulating the catalytic activity of catalase [16].

Mangroves, habitat along the seashore in subtropical and tropical regions, are tolerant to high salinity [17, 18]. The mechanisms to avoid salt-induced oxidative stress in mangrove plants have been extensively studied at cellular and the wholeplant levels. Parida et al. (2004) showed that salinity enhanced the content of $\mathrm{H}_{2} \mathrm{O}_{2}$ in the leaves of Bruguiera parviflora, but it was detoxified by an increasing activity of antioxidant enzymes, guaiacol peroxidase (GPX), ascorbate peroxidase (APX), glutathione reductase (GR) [3]. Similarly, the oxygenscavenging system in the cytosol contributed to the salt tolerance capacity in B. gymnorrhiza even salt stress leads to the generation of superoxide in the cytosol [19]. These results suggest that up-regulation of antioxidant defenses is, at least, one component of salt tolerance in mangrove plants. However, the relationship between $\mathrm{ABA}, \mathrm{CaM}$ and antioxidant defense under salt stress has not been established in mangroves.

Kandelia candel and B. gymnorrhiza are the two ecologically important mangrove species in southern China. In the present study, we designed experiments of a short term (ST, 24-h) and a long term (LT, 4-weeks) salinity to investigate the $\mathrm{NaCl}$-induced variations of endogenous $\mathrm{ABA}, \mathrm{CaM}$ and activity of antioxidant enzymes in the two mangroves. Inhibitors of $\mathrm{ABA}$ and CaM synthesis were used to confirm the enhancement of stress signals on antioxidant defense. We attempted to establish the correlation between ABA, CaM and antioxidant defense in mangroves and to clarify species differences in salt adaptation mechanisms exhibited by the two mangrove species.

\section{MATERIALS AND METHODS}

\section{Plant Materials}

Propagules of Kandelia candel L. Druce and Bruguiera gymnorrhiza were obtained from Dongzhai Harbor in Hainan Province of China (latitude $19^{\circ} 51^{\prime} \mathrm{N}$ and longitude $110^{\circ} 24^{\prime} \mathrm{E}$ ). Hypocotyls were planted in individual pots $(15 \mathrm{~cm}$ in diameter and $18 \mathrm{~cm}$ in height) containing sand and placed in a greenhouse at Beijing Forestry University, China. Plants were irrigated one and two times every day, depending on the evaporative demand, and received with 1 L half strength Hoagland's nutrient solution every 2 weeks. Seedlings were raised from March to July under non-saline conditions. Uniform plants, which were $20 \mathrm{~cm}$ high and had 8 leaves, were used in the following experiments.

\section{Salt Treatments}

\section{Short Term Salinity (24 h, $100 \mathrm{mM} \mathrm{NaCl})$}

The same two treatments were applied for the two species: control and $\mathrm{NaCl}$ stress. Saline treatment was imposed by top watering of $1 \mathrm{~L} 100 \mathrm{mM} \mathrm{NaCl}$ solution at 8:00 AM. Control plants were kept well-watered with no addition of $\mathrm{NaCl}$. Destructive harvests were made after $1,4,8$, and $24 \mathrm{~h}$ of exposure to the initial saline treatment. Three replicated plants per treatment were harvested at each sampling time. Fully expanded leaves were sampled from upper shoots, immediately frozen in liquid nitrogen and stored at $-80^{\circ} \mathrm{C}$ for abscisic acid (ABA), calmodulin (CaM) and antioxidant enzymes (superoxide dismutase, SOD and peroxidase, POD) analyses.

\section{Long Term Salinity (4 weeks, 100-400 mM NaCl)}

$\mathrm{NaCl}$ concentration started from $100 \mathrm{mM}$ and increased stepwise by weekly $100 \mathrm{mM}$, reaching $400 \mathrm{mM}$ in the fourth week. Control plants were kept well watered with no addition of $\mathrm{NaCl}$. Leaves were sampled weekly and three replicated plants per treatment were harvested. Following gas exchange measurements leaves were harvested and the malondialdehyde (MDA) content and membrane permeability (MP) were immediately measured. Then the rest samples were frozen in liquid nitrogen and stored at $-80^{\circ} \mathrm{C}$ for $\mathrm{ABA}, \mathrm{CaM}, \mathrm{SOD}, \mathrm{POD}$ and ion analyses.

\section{Introduction of ABA and CaM Inhibitors}

Potted seedlings of $K$. candel were treated with ABA inhibitor, sodium tungstate $(1000 \mathrm{~mL}, 5 \mathrm{mM})$ [20] and $B$. gymnorrhiza seedlings were treated with $\mathrm{CaM}$ inhibitor, trifluoperazine (TFP) $(1000 \mathrm{~mL}, 50 \mu \mathrm{M})$. Ten to 12 plants of each species were used for applying the inhibitors and same number of control plants was irrigated with the same amount of water. After 24 hours of inhibitors application, plants treated with or without inhibitors were subjected to a 4-h salt stress $(100 \mathrm{mM} \mathrm{NaCl})$ and no-salt controls were kept well watered. Then leaves from three replicated plants per treatment were sampled and immediately frozen under liquid nitrogen and stored at $-80^{\circ} \mathrm{C}$ for antioxidant enzymes analyses, e.g. SOD, ascorbate peroxidase (APX), catalase (CAT) and glutathione reductase (GR).

\section{Gas Exchange Measurement}

Diel courses of net photosynthetic rates (Pn), unit transpiration rate $(\mathrm{Tr})$ and stomatal conductance $(\mathrm{Gs})$ of upper mature leaves were measured, from 8:00 AM to 20:00 PM, with a CIRAS-2 portable photosynthesis system (PP Systems Ltd. U.K.) under natural conditions where the air temperature (Tair) was 25 to $35^{\circ} \mathrm{C}$ and photosynthetically active radiation (PAR) was 1000 to $1200 \mu \mathrm{molm}^{-2} \mathrm{~s}^{-1}$, supplied by cool white fluorescent lamps supplemented with dysprosium lamps.

\section{MDA Content}

Standard procedures required for MDA measurement were followed as described in Heath and Packer (1968) [21]. Approximately $0.50 \mathrm{~g}$ (fresh weight) of leaf tissue was homogenized in $1.5 \mathrm{~mL}$ of $5 \%$ trichloroacetic acid (TCA; w/v). The homogenate was centrifuged at $1,500 \mathrm{~g}$ for $10 \mathrm{~min}$, then the supernatant was diluted to $10 \mathrm{~mL}$. A $2 \mathrm{~mL}$ of the diluted extract was mixed with $2 \mathrm{~mL} 0.67 \%$ 2-thiobarbtiuric acid (TBA; w/v). The mixture was incubated in water bath at $100^{\circ} \mathrm{C}$ for $30 \mathrm{~min}$, then centrifuged at $1,500 \mathrm{~g}$ for $10 \mathrm{~min}$. Absorbency of the aqueous phase at 450, 532, and $600 \mathrm{~nm}$ was measured, respectively. MDA content in the aqueous phase was calculated according to following format: $C\left(\mu \mathrm{molL}^{-1}\right)=6.45 \times\left(\mathrm{A}_{532}-\mathrm{A}_{600}\right)$ $0.56 \times \mathrm{A}_{450}$.

\section{Membrane Permeability (MP)}

Thirty leaf discs, $0.2 \mathrm{~cm}$ in diameter, were immersed in 10 $\mathrm{mL}$ distilled water, and a subsequent 30 min vacuum was applied. Then, electrical conductivity $\left(E_{l}\right)$ was measured with DDS-11A conductivity meter (Shanghai precision \& Scientific Instrument, China) at room temperature. Afterwards, leaf discs were incubated in water at $100^{\circ} \mathrm{C}$ for $30 \mathrm{~min}$, and electrical conductivity $\left(E_{2}\right)$ was measured at room temperature. MP was calculated as: $E_{1} / E_{2} \times 100 \%$. 


\section{Leaf Ion Analysis}

Sampled leaves were oven-dried at $65^{\circ} \mathrm{C}$ for 4 days, ground and passed through $1.0 \mathrm{~mm}$ sieve and stored for $\mathrm{Na}^{+}$ and $\mathrm{Cl}^{-}$measurements. $\mathrm{Na}^{+}$was quantified by an atomic absorption spectrophotometer (Perkin-Elmer 2280) and $\mathrm{Cl}^{-}$ by silver titration [22].

\section{ABA Determination}

Approximately $0.5 \mathrm{~g}$ fresh weight samples were ground to fine powder in liquid nitrogen and homogenized in $1.5 \mathrm{~mL}$ extraction solution containing 80\% methanol and $1 \mathrm{mM}$ butylated hydroxytoluene (BHT). Extracts were kept in a refrigerator at $4^{\circ} \mathrm{C}$ for $4 \mathrm{~h}$ and then centrifuged at $1,000 \mathrm{~g}$ for $15 \mathrm{~min}$ at $4^{\circ} \mathrm{C}$. After centrifugation, the residue was reextracted with $1 \mathrm{~mL}$ extraction solution and kept at $4^{\circ} \mathrm{C}$ for 1 $\mathrm{h}$ and then centrifuged as described above. Then, the supernatants were combined and loaded on a C18 column. Thereafter, the eluate was dried by vacuum evaporation. The residue was dissolved in $1 \mathrm{~mL}$ sample diluent and ABA was assayed using an ELISA as described in Wu et al. (1988) [23]. ABA reagent box was obtained from Biotechnology Institute of China Agricultural University (Beijing, China).

\section{CaM Determination}

Approximately $0.5 \mathrm{~g}$ fresh weight samples were ground to fine powder in liquid nitrogen and homogenized in $1.5 \mathrm{~mL}$ extraction buffer containing $150 \mathrm{mM} \mathrm{NaCl}, 2 \mathrm{mM}$ EGTA, 50 $\mathrm{mM}$ Tris, $1 \mathrm{mM} \beta$-mercaptoethanol, $0.25 \mathrm{mM}$ phenylmethylsulphonyl fluoride (PMSF), $20 \mathrm{mM} \mathrm{NaHCO}$ (pH 7.4), Extracts were kept at $95^{\circ} \mathrm{C}$ for $3 \mathrm{~min}$ in a water bath. Then, samples were centrifuged at $10,000 \mathrm{~g}$ for $45 \mathrm{~min}$ at $4^{\circ} \mathrm{C}$ and the supernatant was used for CaM assay. Calmodulin was assayed with an ELISA according to Zhao et al. (1988) [24]. The CaM reagent box was obtained from the Biology Department of Hebei Normal University (Shijiazhuang, China).

\section{Extraction of Antioxidant Enzymes}

Leaf tissue samples (approximately $0.5 \mathrm{~g}$ ) were ground to a powder with liquid nitrogen and homogenized in a $2 \mathrm{~mL}$ of ice-cold extraction buffer: $50 \mathrm{mM}$ sodium phosphate buffer, $\mathrm{pH} 7.8$ (for SOD extraction) or pH5.5 (for POD extraction) and $1 \%$ PVPP-40. The extracts were centrifuged at $10,000 \mathrm{~g}$ for $20 \mathrm{~min}$ at $4^{\circ} \mathrm{C}$, and the supernatant was used for enzyme assays.

\section{Superoxide Dismutase (SOD)}

Total SOD activity was measured by monitoring the superoxide radical-induced nitro blue tetrazolium (NBT) reduction at $560 \mathrm{~nm}$ [25]. The modifications were described in Wang et al. (2006) [7].

\section{Peroxidase (POD)}

Guaiacol-dependent peroxidase activity was measured according to the method of Kochba et al. (1977) [26] with modifications [7].

\section{Ascorbate Peroxidase (APX)}

Total APX activity was assayed as described in Mishra et al. (1993) [27]. The reaction mixture contained $50 \mathrm{mM}$ potassium phosphate ( $\mathrm{pH} 7.0), 15 \mathrm{mM}$ ascorbic acid and 30
$\mathrm{mM} \mathrm{H} \mathrm{O}_{2}$ and enzyme extract (containing $20 \mu \mathrm{g}$ of protein). The reaction at $25^{\circ} \mathrm{C}$ was initiated by the addition of $\mathrm{H}_{2} \mathrm{O}_{2}$. APX activity was immediately measured by recording the decrease in absorbance at $290 \mathrm{~nm}$.

\section{Catalase (CAT)}

Total CAT activity was determined spectrophotometrically by measuring the rate of $\mathrm{H}_{2} \mathrm{O}_{2}$ consumption at $240 \mathrm{~nm}$. The reaction mixture contained $50 \mathrm{mM}$ potassium phosphate ( $\mathrm{pH}$ 7.0) and $10.5 \mathrm{mM} \mathrm{H}_{2} \mathrm{O}_{2}$ [28]. Immediately after the addition of enzyme extract (containing $20 \mu \mathrm{g}$ protein), the initial linear rate of decrease in absorbance at $240 \mathrm{~nm}$ was used to calculate the activity.

\section{Glutathione Reductase (GR)}

Total GR activity was determined at $25^{\circ} \mathrm{C}$ by measuring the rate of NADPH oxidation [29]. The reaction mixture (3 $\mathrm{mL})$ contained $50 \mathrm{mM}$ potassium phosphate $(\mathrm{pH} 7.8), 2 \mathrm{mM}$ $\mathrm{Na}_{2}$ EDTA, $0.15 \mathrm{mM}$ NADPH, $0.5 \mathrm{mM}$ oxidized glutathione (GSSG) and $50 \mu \mathrm{L}$ of enzyme. NADPH was added to start the reaction and the decrease in absorbance at $340 \mathrm{~nm}$ was recorded as soon as the reaction began.

\section{Data Analysis}

The data were subjected to ANOVA and significant differences between means were determined by Duncan's multiple-range test. Unless otherwise stated, differences were considered statistically significant when $p<0.05$.

\section{RESULTS}

\section{The Response of Two Mangrove Species to Short Term Salinity}

\section{$A B A$ and $C a M$}

Leaf $\mathrm{ABA}$ and $\mathrm{CaM}$ concentrations in control plants of the two species fluctuated over the observation period (Fig. 1), presumably resulting from variations in light intensity and air temperature (Fig. 2). Leaf ABA in $K$. candel markedly increased to $297.7 \mathrm{ngg}^{-1} \mathrm{FW}$ after $4 \mathrm{~h}$ of $\mathrm{NaCl}$ treatment, which was 1.3-fold of that in controls (Fig. 1). Thereafter salinised plants maintained higher ABA than control plants in the following hours (Fig. 1). In contrast to $K$. candel plants, $\mathrm{NaCl}$ did not increase $\mathrm{ABA}$ in $B$. gymnorrhiza leaves (Fig. 1).

Leaf CaM concentrations in the two species were remained at control levels after the initiation of salt stress, but a $41-62 \%$ increase was observed in $K$. candel and $B$. gymnorrhiza at $24 \mathrm{~h}$ (Fig. 1).

\section{Antioxidant Enzymes}

SOD activity in $K$. candel markedly increased after the first hour of exposure to salinity and remained constant until $4 \mathrm{~h}$, followed by a sharp rise and reached the highest level at

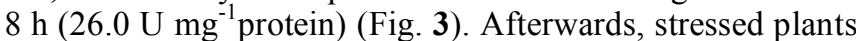
maintained higher SOD activity until the terminal of experiment (Fig. 3). B. gymnorrhiza exhibited a transient SOD increase after salt stress was initiated, but SOD activity returned to control levels after 8 hours of stress (Fig. 3).

Compared with control B. gymnorrhiza plants, control $K$. candel plants had typically higher POD activity (Fig. 3). Noteworthy, there is marked difference in the pattern of 
K. candel
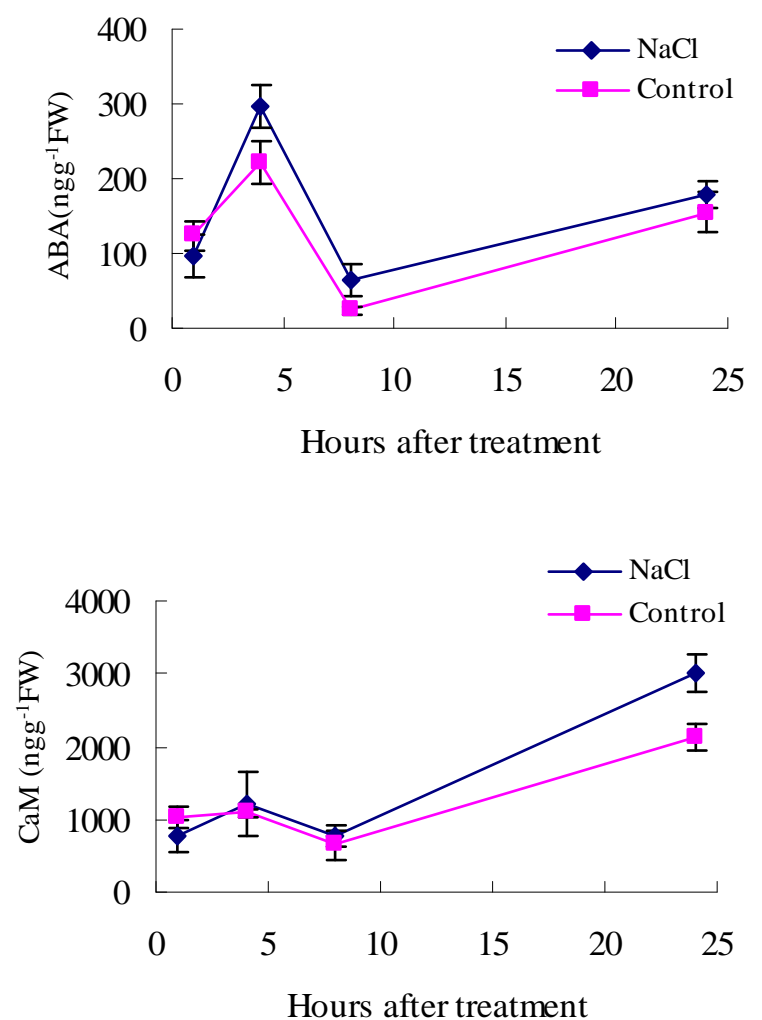

B. gymnorrhiza
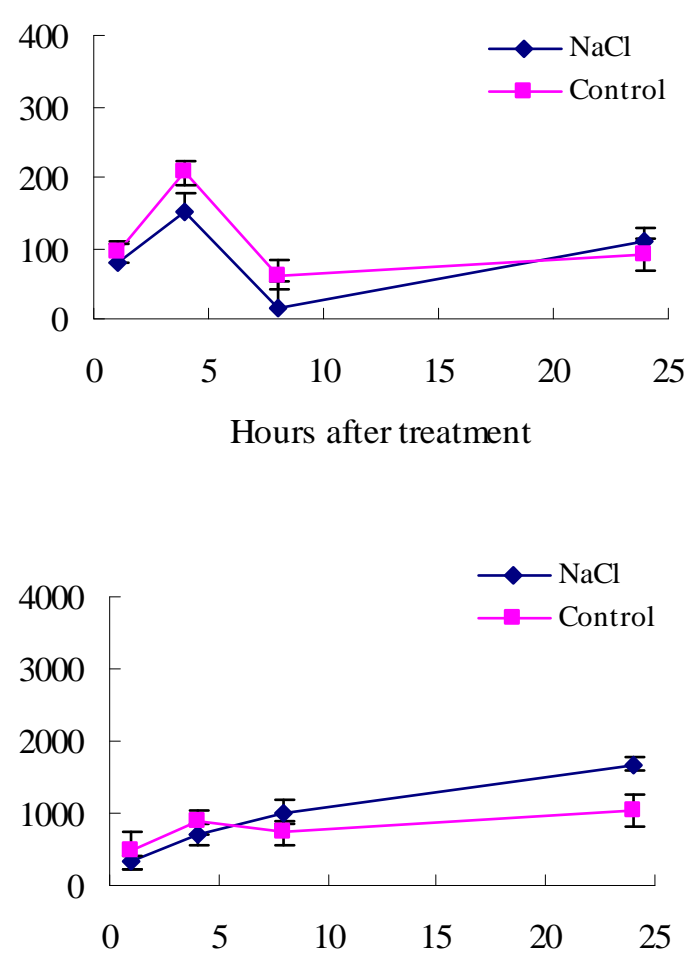

Hours after treatment

Fig. (1). Leaf abscisic acid (ABA) and calmodulin (CaM) concentrations in $K$. candel and B. gymnorrhiza after exposure to a short term salinity $(24 \mathrm{~h}, 100 \mathrm{mM} \mathrm{NaCl}) . \mathrm{NaCl}$ was applied at 8:00 AM, and leaves were sampled after 1, 4, 8, and 24 hours of treatment. On the harvest day, air temperature (Tair) was 25 to $36^{\circ} \mathrm{C}$ and photosynthetically active radiation (PAR) ranged from 58 to $1505 \mu \mathrm{molm} \mathrm{s}^{-2}$. Each point is the mean of three plants and bars represent the standard error of the mean.

POD response to salinity between the two mangroves. POD activity in B. gymnorrhiza leaves sharply increased from 95.6 to $573.6 \mathrm{Umg}^{-1}$ protein as soon as salt stress began (Fig. 3). It increased steadily and reaching the highest level at 8 hours, up to $920.7 \mathrm{Umg}^{-1}$ protein (Fig. 3). POD activity in $K$. candel leaves was found to increase at 8 hours and declined to control levels following the same trend of POD in $B$. gymnorrhiza (Fig. 3).

\section{The Response of Two Mangrove Species to Long term} Salt Stress

\section{Gas Exchange}

Stomatal conductance (Gs), net photosynthetic rate $(\mathrm{Pn})$ and unit transpiration rate (Tr) declined with the increasing duration of salt stress in the two species, but the inhibitory effects of salinity were more pronounced in $K$. candel, especially at high salinity ( $400 \mathrm{mM} \mathrm{NaCl}, 4$ th week): leaf gas exchange decreased by $76-87 \%$ in $K$. candel, whereas $B$. gymnorrhiza exhibited a lesser reduction, 55-70\% (Table 1).

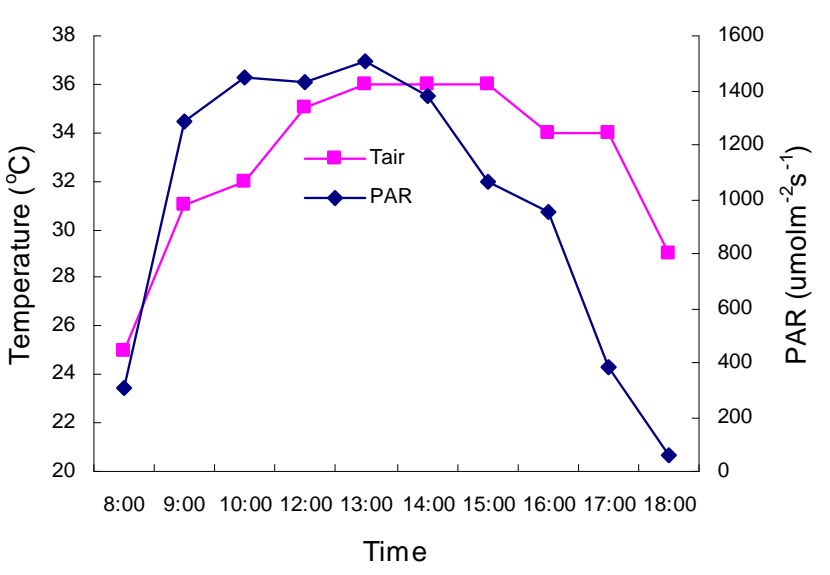

Fig. (2). Diurnal courses of air temperature (Tair) and photosynthetically active radiation (PAR) in the short term salt treatment. 
K. candel

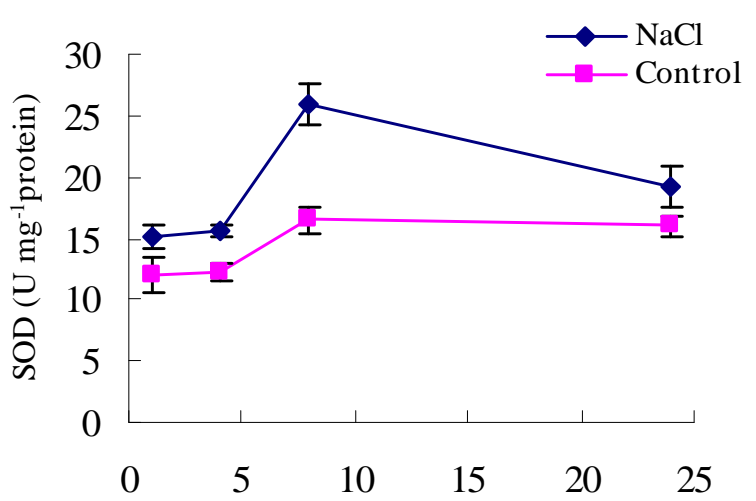

Hours after treatment

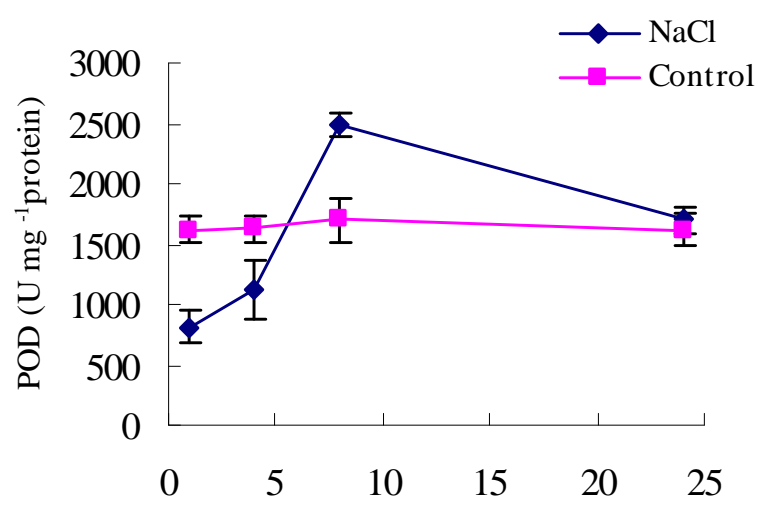

Hours after treatment
B. gymnorrhiza

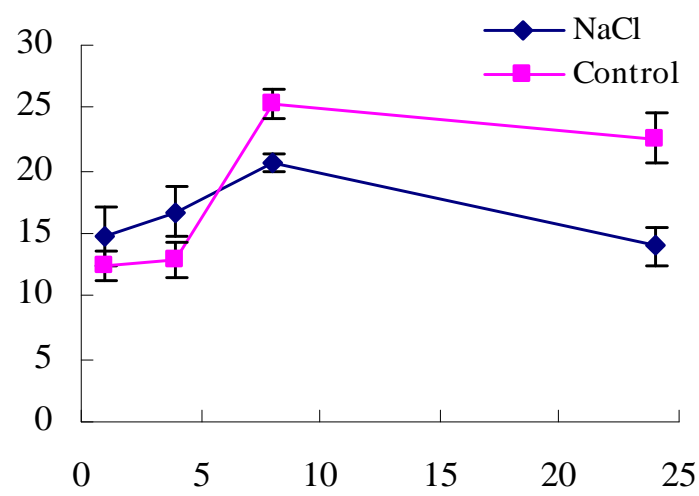

Hours after treatment

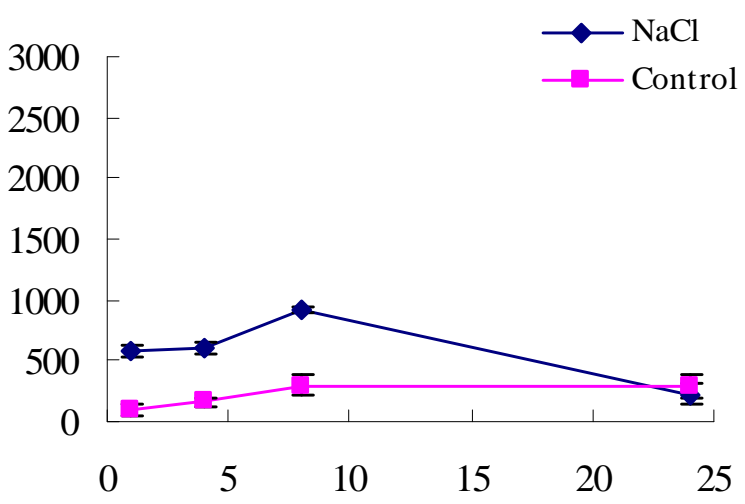

Hours after treatment

Fig. (3). Total superoxide dismutase (SOD) activity and total peroxidase (POD) activity in leaves of K. candel and B. gymnorrhiza after exposure to a short term salinity $(24 \mathrm{~h}, 100 \mathrm{mM} \mathrm{NaCl})$. Each point is the mean of three plants and bars represent the standard error of the mean.

\section{$A B A$ and $C a M$}

Leaf ABA concentration in $K$. candel plants increased rapidly after salt exposure and reached to the maximum at the 2nd week, which was 2.2-fold that in controls (Fig. 4). Thereafter, it returned to control levels despite a notable decline of ABA in control plants at the end of experiment (Fig. 4). ABA concentration in salinised B. gymnorrhiza plants did not significantly differ from controls over the duration of 4-weeks stress (Fig. 4).

Salt-induced CaM accumulation was clearly seen in the two mangrove species at the 1st week (Fig. 4); however, $B$. gymnorrhiza maintained typically a higher CaM increase during the period of increasing salinity, as compared to $K$. candel (Fig. 4).

\section{SOD and POD Activity}

Salinity increased SOD activity in the two mangroves but there were species differences in the pattern of the SOD response to salinity (Fig. 5). Stressed $K$. candel exhibited a transient SOD increase at a lower $\mathrm{NaCl}$ concentration (100 $\mathrm{mM}, 1$ st week) whereas salt-induced SOD in B. gymnorrhiza took place at a higher salinity $(400 \mathrm{mM} \mathrm{NaCl}$, 4th week) (Fig. 5).

Leaf POD activity in $K$. candel was significantly enhanced by higher saline (300-400 $\mathrm{mM} \mathrm{NaCl}$, 3rd and 4th week), whereas there were no corresponding changes in $B$. gymnorrhiza (Fig. 5). Noteworthy, $K$. candel maintained typically higher POD activity than $B$. gymnorrhiza regardless of treatments (Fig. 5).

\section{Sodium and Chloride Concentrations}

Control plants of $K$. candel and B. gymnorrhiza had evident $\mathrm{Na}^{+}$and $\mathrm{Cl}^{-}$in leaves, 0.32-0.44 mmolg ${ }^{-1} \mathrm{DW}$ (Table 2). $\mathrm{Na}^{+}$and $\mathrm{Cl}^{-}$levels in the two mangroves gradually increased corresponding to the increased concentration of $\mathrm{NaCl}$ and timing of exposure to salinity, reaching $0.55-0.63$ mmolg ${ }^{-1} \mathrm{DW}\left(\mathrm{Na}^{+}\right)$and $0.68-0.85 \mathrm{mmolg}^{-1} \mathrm{DW}\left(\mathrm{Cl}^{-}\right)$, respectively, at the 4 th week $(400 \mathrm{mM} \mathrm{NaCl})$, but higher levels were observed in B. gymnorrhiza leaves (Table 2). 
Table 1. Effect of NaCl on Stomatal Conductance (Gs), Unit Transpiration Rate (Tr) and Net Photosynthetic Rate (Pn) in $K$. candel and B. gymnorrhiza Leaves

\begin{tabular}{|c|c|c|c|c|c|c|}
\hline \multirow{2}{*}{ Treatment } & \multicolumn{3}{|c|}{ K. candel } & \multicolumn{3}{|c|}{ B. gymnorrhiza } \\
\hline & 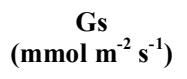 & $\begin{array}{c}\operatorname{Tr} \\
\left(\mathbf{m m o l ~ m ^ { - 2 }} \mathbf{s}^{-1}\right)\end{array}$ & $\underset{\left(\mu \mathrm{mol} \mathrm{m} \mathrm{m}^{-2} \mathrm{~s}^{-1}\right)}{\text { Pn }}$ & 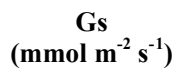 & $\begin{array}{c}\operatorname{Tr} \\
\left(\mathbf{m m o l ~ m ^ { - 2 }} \mathbf{s}^{-1}\right)\end{array}$ & $\underset{\left(\mu \mathrm{mol} \mathrm{m} \mathrm{m}^{-2} \mathrm{~s}^{-1}\right)}{\text { Pn }}$ \\
\hline Control & $148.4 \pm 55.4 \mathrm{a}$ & $3.72 \pm 0.99 \mathrm{a}$ & $7.21 \pm 1.63 \mathrm{a}$ & $101.4 \pm 38.1 \mathrm{a}$ & $2.90 \pm 0.84 \mathrm{a}$ & $5.56 \pm 2.20 \mathrm{a}$ \\
\hline $\mathrm{NaCl}$ (week 1) & $108.4 \pm 38.2 \mathrm{ab}$ & $2.99 \pm 0.90 \mathrm{ab}$ & $5.61 \pm 1.25 \mathrm{ab}$ & $82.7 \pm 24.9 \mathrm{ab}$ & $2.40 \pm 0.69 \mathrm{ab}$ & $4.34 \pm 2.17 \mathrm{ab}$ \\
\hline $\mathrm{NaCl}$ (week 2) & $87.9 \pm 29.4 b$ & $2.80 \pm 1.02 \mathrm{~b}$ & $5.05 \pm 1.46 \mathrm{~b}$ & $77.4 \pm 26.5 b$ & $2.20 \pm 0.64 b$ & $4.00 \pm 1.80 \mathrm{~b}$ \\
\hline $\mathrm{NaCl}$ (week 3) & $83.6 \pm 27.6 \mathrm{~b}$ & $2.49 \pm 1.07 \mathrm{~b}$ & $4.15 \pm 1.27 b$ & $75.9 \pm 25.5 b$ & $1.79 \pm 0.74 b$ & $3.62 \pm 1.96 b$ \\
\hline $\mathrm{NaCl}$ (week 4) & $20.0 \pm 8.0 \mathrm{c}$ & $0.91 \pm 0.67 \mathrm{c}$ & $1.42 \pm 1.04 \mathrm{c}$ & $30.3 \pm 6.02 c$ & $1.30 \pm 0.58 \mathrm{c}$ & $2.24 \pm 1.16 c$ \\
\hline
\end{tabular}

Note: $\mathrm{NaCl}$ concentration started from $100 \mathrm{mM}$ at the 1st week and increased stepwise by weekly $100 \mathrm{mM}$, reaching $400 \mathrm{mM}$ in the fourth week. Gas exchange was measured every

2 hours from 8:00 AM to 18:00 PM and the daily average value is given. Each value $( \pm \mathrm{SE})$ is the mean of three individual plants and values in the same column followed by different letters are significantly different $(P<0.05)$ between control and $\mathrm{NaCl}$ treatment.

K. candel

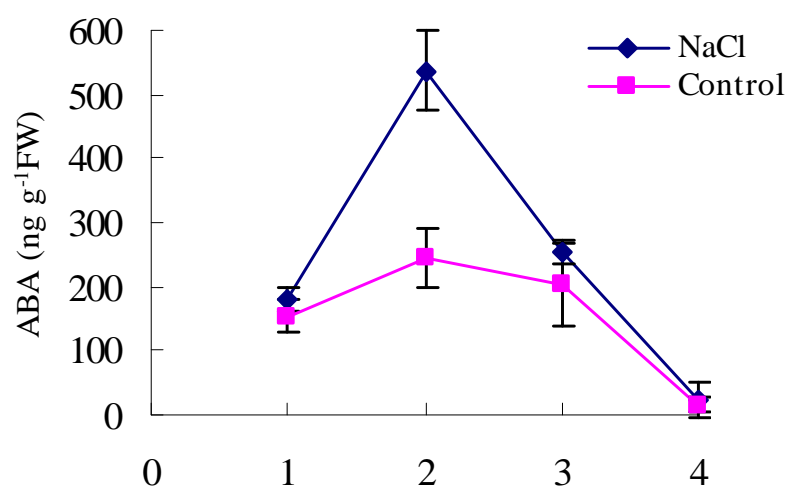

Weeks after treatment

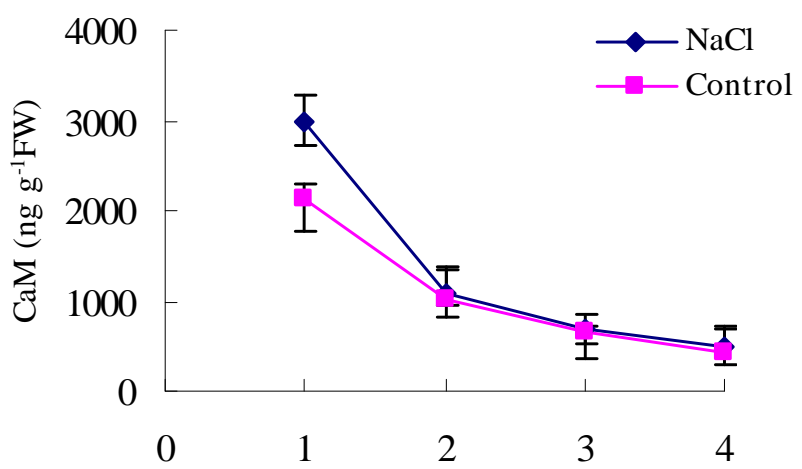

Weeks after treatment
B. gymnorrhiza

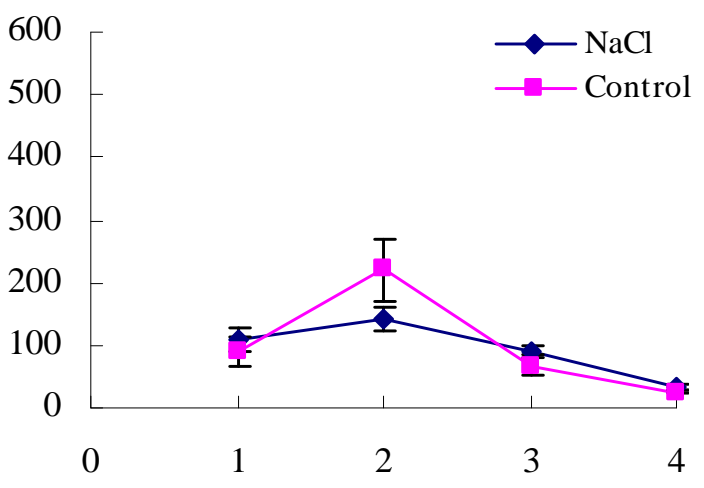

Weeks after treatment

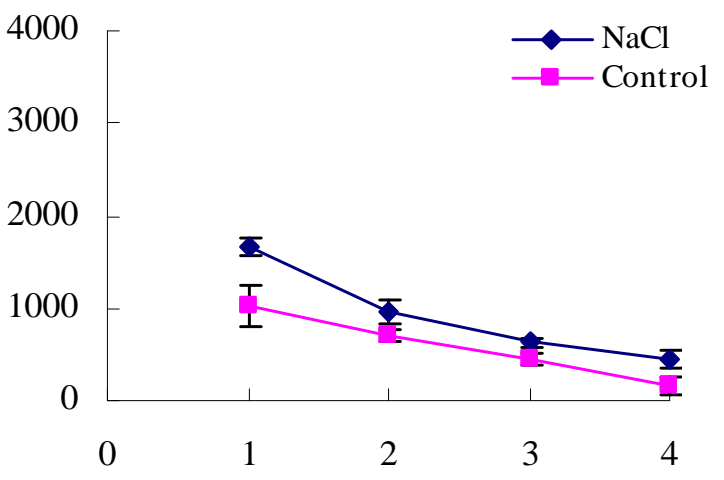

Weeks after treatment

Fig. (4). Leaf abscisic acid (ABA) and calmodulin (CaM) concentrations in K. candel and B. gymnorrhiza after exposure to a long term salinity. $\mathrm{NaCl}$ concentration started from $100 \mathrm{mM}$ at the 1 st week and increased stepwise by weekly $100 \mathrm{mM}$, reaching $400 \mathrm{mM}$ in the fourth week. Each point is the mean of three plants and bars represent the standard error of the mean. 
K. candel
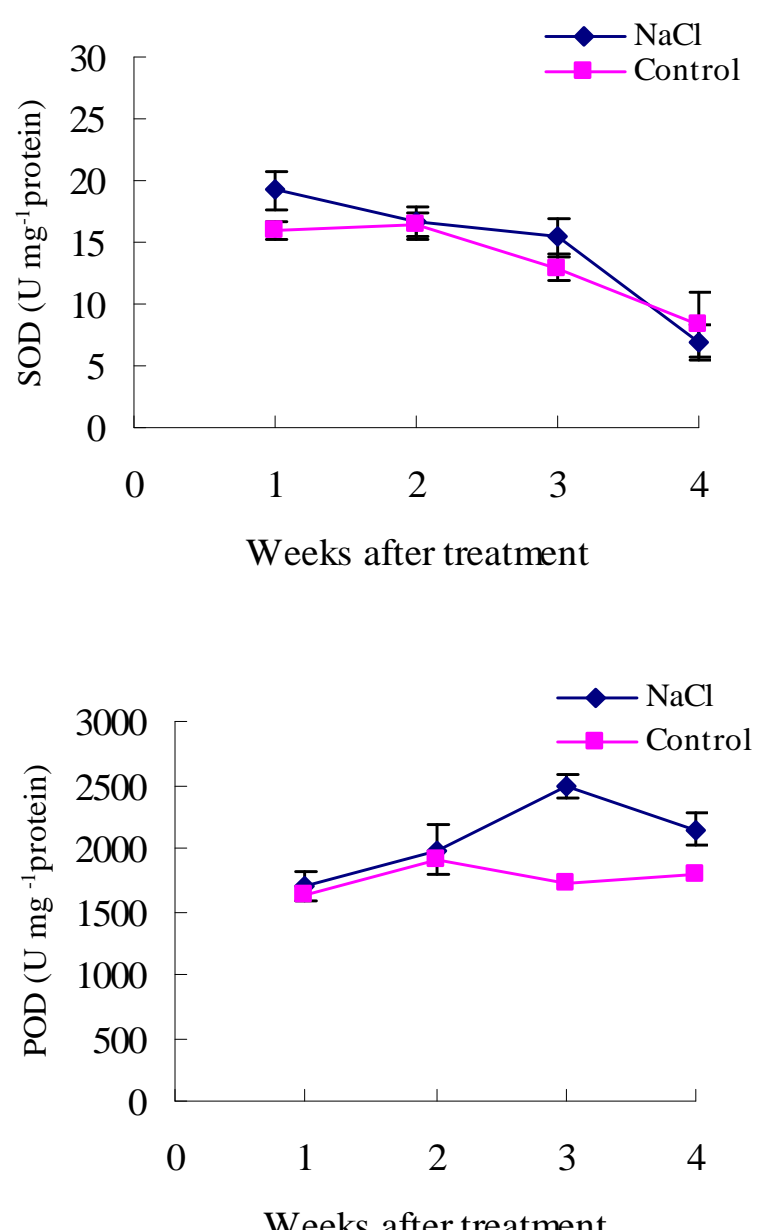

B. gymnorrhiza
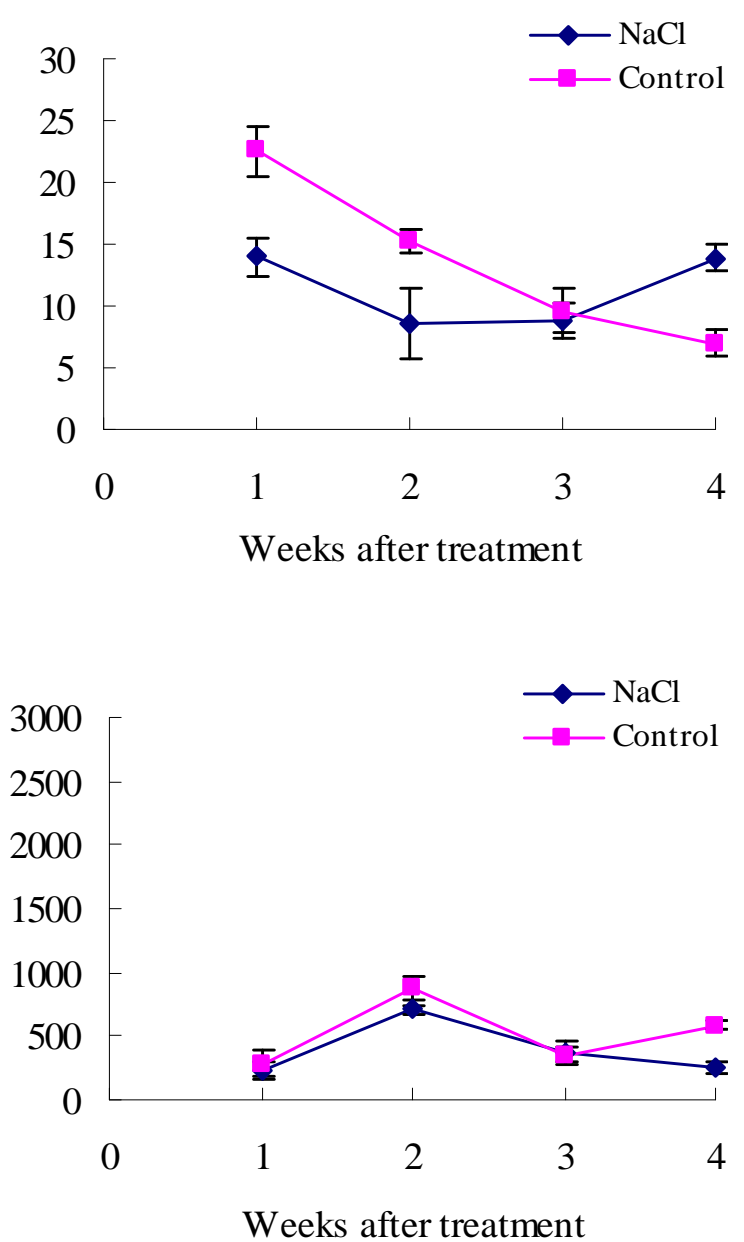

Fig. (5). Total SOD activity and total POD activity in leaves of $K$. candel and B. gymnorrhiza after exposure to a long term salinity. NaCl concentration started from $100 \mathrm{mM}$ at the 1 st week and increased stepwise by weekly $100 \mathrm{mM}$, reaching $400 \mathrm{mM}$ in the fourth week. Each point is the mean of three plants and bars represent the standard error of the mean.

\section{MDA Content and Membrane Permeability}

Leaf MDA contents in NaCl-treated plants of $B$. gymnorrhiza and $K$. candel remained at a level similar to those in controls during 4 weeks of stress, although a 21$22 \%$ increase was observed in the two species at the end of experiment (400 $\mathrm{mM} \mathrm{NaCl})$ (Table 2). Similarly, increasing salinity did not significantly increase MP in B. gymnorrhiza and $K$. candel leaves despite a $23-32 \%$ rise at the 4 th week (Table 2).

\section{Effects of ABA and CaM Inhibitors on Antioxidant Enzymes}

The inhibitory effects of tungstate (sodium form, ABA synthesis inhibitor) and TFP (CaM inhibitor) on salt-induced antioxidant enzymes (SOD, APX, GR and CAT) were investigated in this study. Activity of SOD, APX and CAT in leaves of the two species was elevated by the saline treatment, but the $\mathrm{NaCl}$-induced enhancement of antioxidant enzymes was inhibited by tungstate in $K$. candel and by TFP in B. gymnorrhiza (Fig. 6).

\section{DISCUSSION}

\section{Leaf Salt Accumulation, Malondialdehyde Content and Membrane Permeability}

In general, excessive salt buildup in leaves causes oxidative damage in plants. Our previous studies have shown that the increased membrane permeability in the two saltsensitive Populus, $P$. deltoides $\times P$. nigra (Dode) Guinier cv. I-214 ( $P$. cv. I-214) and $P$. simonii $\times(P$. pyramidalis $\times$ Salix matsudana) ( $P$. popularis cv. '35-44', $P$. popularis) is associated with $\mathrm{Na}^{+}$and $\mathrm{Cl}^{-}$accumulation in leaves [7]. Saltinduced reduction of SOD and POD activity in salt-sensitive poplars may decrease the capacity for active oxygenscavenging, causing oxidative burst and leaf damage [8]. In the present study, concentrations of $\mathrm{Na}^{+}$and $\mathrm{Cl}^{-}$in leaves of LT-stressed B. gymnorrhiza and K. candel greatly increased coincident with increasing soil $\mathrm{NaCl}$ (Table 2), but leaf 
Table 2. Effects of $\mathrm{NaCl}$ on $\mathrm{Na}^{+}, \mathrm{Cl}^{-}$, Malondialdehyde (MDA) Content and Membrane Permeability (MP) in $\mathrm{K}$. candel and $\mathrm{B}$. gymnorrhiza Leaves

\begin{tabular}{|c|c|c|c|c|c|}
\hline Species & Treatment & $\begin{array}{c}\mathrm{Na}^{+} \\
\text {mmolg }^{-1} \mathrm{DW}\end{array}$ & $\underset{\text { mmolg }^{-1} \mathrm{DW}}{\mathrm{Cl}^{-}}$ & $\underset{\text { nmolg }^{-1} \text { FW }}{\text { MDA }}$ & $\begin{array}{c}\text { MP } \\
\%\end{array}$ \\
\hline \multirow{5}{*}{ K.candel } & Control & $0.32 \pm 0.04 \mathrm{~b}$ & $0.44 \pm 0.06 \mathrm{~b}$ & $5.44 \pm 0.63 \mathrm{a}$ & $22.41 \pm 1.07 \mathrm{a}$ \\
\hline & $\mathrm{NaCl}$ (week 1) & $0.34 \pm 0.05 b$ & $0.53 \pm 0.05 b$ & $4.92 \pm 0.33 \mathrm{a}$ & $24.48 \pm 1.69 \mathrm{a}$ \\
\hline & $\mathrm{NaCl}$ (week 2) & $0.41 \pm 0.03 \mathrm{a}$ & $0.58 \pm 0.02 \mathrm{a}$ & $5.60 \pm 1.20 \mathrm{a}$ & $25.05 \pm 0.41 \mathrm{a}$ \\
\hline & $\mathrm{NaCl}$ (week 3) & $0.45 \pm 0.02 \mathrm{a}$ & $0.59 \pm 0.05 \mathrm{a}$ & $4.73 \pm 1.18 \mathrm{a}$ & $28.08 \pm 0.59 a$ \\
\hline & $\mathrm{NaCl}$ (week 4) & $0.55 \pm 0.05 \mathrm{a}$ & $0.68 \pm 0.07 \mathrm{a}$ & $6.62 \pm 0.95 \mathrm{a}$ & $29.80 \pm 2.01 \mathrm{a}$ \\
\hline \multirow{5}{*}{ B. gymnorrhiza } & Control & $0.38 \pm 0.04 \mathrm{~b}$ & $0.44 \pm 0.08 \mathrm{~b}$ & $6.67 \pm 0.78 \mathrm{a}$ & $22.44 \pm 1.08 \mathrm{a}$ \\
\hline & $\mathrm{NaCl}$ (week 1) & $0.39 \pm 0.05 b$ & $0.77 \pm 0.09 \mathrm{a}$ & $4.59 \pm 0.38 \mathrm{a}$ & $21.12 \pm 1.42 \mathrm{a}$ \\
\hline & $\mathrm{NaCl}$ (week 2) & $0.40 \pm 0.04 \mathrm{~b}$ & $0.80 \pm 0.08 \mathrm{a}$ & $7.84 \pm 0.05 \mathrm{a}$ & $23.83 \pm 0.91 \mathrm{a}$ \\
\hline & $\mathrm{NaCl}$ (week 3) & $0.48 \pm 0.02 \mathrm{a}$ & $0.84 \pm 0.11 \mathrm{a}$ & $6.04 \pm 0.76 \mathrm{a}$ & $25.23 \pm 0.44 a$ \\
\hline & $\mathrm{NaCl}$ (week 4) & $0.63 \pm 0.05 \mathrm{a}$ & $0.85 \pm 0.09 \mathrm{a}$ & $8.14 \pm 0.73 \mathrm{a}$ & $27.65 \pm 1.33 \mathrm{a}$ \\
\hline
\end{tabular}

Note: $\mathrm{NaCl}$ concentration started from $100 \mathrm{mM}$ at the 1st week and increased stepwise by weekly $100 \mathrm{mM}$, reaching $400 \mathrm{mM}$ in the fourth week. Control plants were kept well watered with no addition of $\mathrm{NaCl}$. Each value $( \pm \mathrm{SE})$ is the mean of three individual plants and values in the same column followed by different letters are significantly different $(P$ $<0.05$ ) between control and $\mathrm{NaCl}$ treatment.

MDA content (a product of lipid peroxidation) and MP in the two mangrove had no marked increase during the period of salt stress (Table 2), implying that the 4-weeks of increasing salinity, up to $400 \mathrm{mM} \mathrm{NaCl}$, did not induce lipid peroxidation and membrane leakage. Results showed that both $K$. candel and B. gymnorrhiza were able to maintain membrane integrity under increasing saline conditions, which was resulted, at least in part, from up-regulation of antioxidant enzymes in response to salinity.

\section{Antioxidant Enzymes Response to Salinity}

Under saline conditions, salt-tolerant plants modulate the level of antioxidant enzymes to alleviate oxidative damage that initiated by ROS [6, 30-36]. SOD and POD have been considered as the two key enzymes in ROS elimination [31, $37,38]$. Results showed that the two mangrove species both triggered antioxidant defense in response to salt stress, but with different patterns regardless of salt treatments, short term stress or long term salt adaptation.

Upon a short term salinity (24h, $100 \mathrm{mM} \mathrm{NaCl}), B$. gymnorrhiza up-regulated POD activity coincident with the increase of SOD (Fig. 3), showing an elevated capacity to detoxify ROS (superoxide radical, $\mathrm{O}_{2}^{-}$and $\mathrm{H}_{2} \mathrm{O}_{2}$ ). Leaf SOD activity in $K$. candel significantly increased immediately after salt stress began, but there was no corresponding change in POD activity (Fig. 3). Salt-induced increase in POD took place at $8 \mathrm{~h}$ (Fig. 3), which was presumably induced by $\mathrm{H}_{2} \mathrm{O}_{2}$ in $K$. candel leaves. The elevation of SOD increased the conversion of superoxide radical into hydrogen peroxide [39], which may initiate POD activity since $\mathrm{H}_{2} \mathrm{O}_{2}$ has been considered as secondary messengers to induce antioxidant defenses [40-42]. Collectively, a coincident increase in SOD and POD activity after a short term of salt exposure is required for rapid removal of ROS, thus avoids oxidative burst and the subsequent oxidative damage in the two mangrove species [43].

There were also species differences in the pattern of antioxidant enzymes response to a prolonged period of increasing salinity. High saline (400 $\mathrm{mM} \mathrm{NaCl}$, 4th week) induced a marked rise of SOD in B. gymnorrhiza leaves whereas the effects of salt stress were less pronounced in POD (Fig. 5). Conversely, high salinity (300-400 mM NaCl, 3 rd and 4th week) increased POD activity but did not induce SOD activity in $K$. candel (Fig. 5). In any cases, the elevation of SOD or POD avoids excessive $\mathrm{O}_{2}^{-}$and $\mathrm{H}_{2} \mathrm{O}_{2}$, which may generate even highly reactive hydroxyl radicals $(\cdot \mathrm{OH})$ by a metal-catalyzed site-specific Haber-Weiss reaction [44].

\section{ABA and CaM Response to Salinity and the Relevance to Salt Tolerance in Mangroves}

\section{$A B A, C a M$ and Ion Homeostasis}

Compared with B. gymnorrhiza, $K$. candel showed a higher capacity to exclude salt under increasing salinity (Table 2), which may partially result from the marked ABA accumulation over the duration of salt exposure (Figs. 1, 4) since ABA limits $\mathrm{Na}^{+}$and $\mathrm{Cl}^{-}$concentration in leaves [10, 45]. Leaf ABA content in $K$. candel increased significantly at the beginning of salt treatment, but it remained unchanged in B. gymnorrhiza (Fig. 1), indicating that $K$. candel is more sensitive to sense soil salinity as compared to $B$. gymnorrhiza. A similar trend was found in a longer-term salinity in which salt-induced ABA synthesis is more evident in $K$. candel (Fig. 4). The rapid increase in ABA in $K$. candel may result from activation of ABA biosynthetic genes, which is probably mediated by a $\mathrm{Ca}^{2+}$-dependent phosphorelay cascade $[46,47]$. Unlike $K$. candel, stressed $B$. gymnorrhiza exhibited a more pronounced $\mathrm{CaM}$ accumulation, especially under increasing saline conditions (Fig. 4). ABA is a stomatal regulator [48, 49] and recent studies show that CaM may participate in salt-induced stomatal closure in Populus [50, 51]. Accordingly, saltinduced $\mathrm{ABA}$ and/or CaM caused stomatal closure in the two mangroves and decreased gas exchange (Table 1), thus reducing the water flow and the amount of salt ions transport to leaves is consequently limited. Similarly, we found that a sustained increase in ABA concentration contributed to the 
limitation of root-shoot salt transport in a salt-tolerant species, Populus euphratica [13, 14, 52, 53].

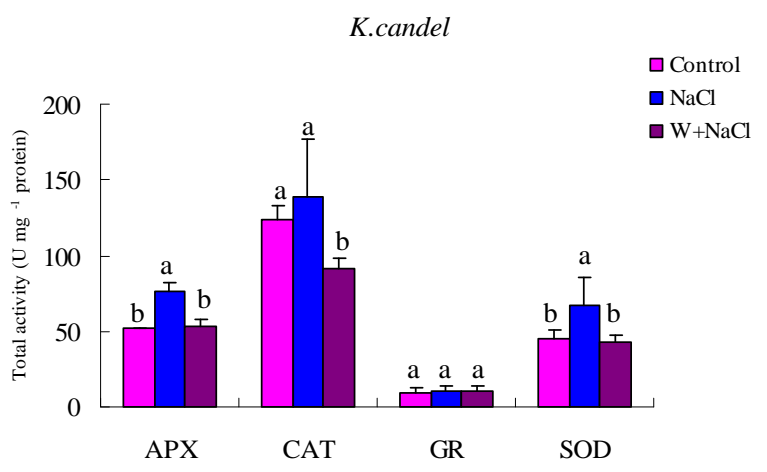

B.gymnorhiza

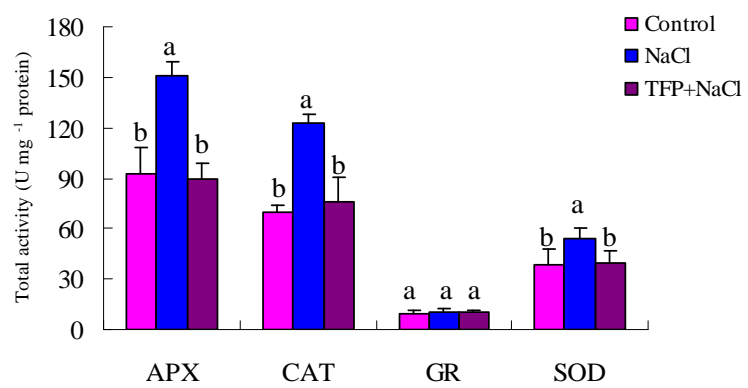

Fig. (6). Effects of tungstate (sodium form, ABA synthesis inhibitor) (W) and trifluoperazine (TFP, CaM inhibitor) on $\mathrm{NaCl}$ induced activity of antioxidant enzymes, ascorbate peroxidase (APX), catalase (CAT), glutathione reductase (GR) and superoxide dismutase (SOD) in leaves of K. candel and B. gymnorrhiza. Each point is the mean of three plants and bars represent the standard error of the mean. Controls represent the mean values of nonsalinised plants treated with or without inhibitors (there were no significant effects of inhibitors on antioxidant enzymes under nosalt control conditions). Columns marked with a different letters are significantly different at $P<0.05$.

\section{$A B A, C a M$ and Antioxidant Defense}

ABA is able to induce gene expression of antioxidant enzymes, as well as their activity in plants [54]. ABA concentration in $K$. candel significantly increased after $4 \mathrm{~h}$ of salt treatment (Fig. 1), and salt-induced SOD and POD activity reached the maximum at $8 \mathrm{~h}$ (Fig. 3). In addition to a transitory increase of ABA at the beginning of salt stress, $K$. candel remained higher ABA during the period of increasing salinity and antioxidant enzymes, especially POD, were maintained at a higher level under high saline conditions (Figs. 4, 5). Moreover, the application of ABA synthesis inhibitor tungstate (sodium form) [20] (Fig. 6) was found to reduce the $\mathrm{NaCl}$-induced activity of SOD and APX in $K$. candel leaves. Therefore, we conclude that salt stressinduced $\mathrm{ABA}$ accumulation leads to up-regulation of the antioxidant defense in $K$. candel plants.
$\mathrm{CaM}$ in $B$. gymnorrhiza leaves gradually increased upon a 24-h salt treatment (Fig. 1), and SOD and POD activity increased correspondingly (Fig. 3). In a LT NaCl treatment, B. gymnorrhiza showed a steady CaM accumulation (Fig. 4), and a marked increase of SOD activity was found at the end of experiment (400 mM NaCl) (Fig. 5). Yang and poovaiah (2002) suggest that $\mathrm{Ca}^{2+} / \mathrm{CaM}$ decreases $\mathrm{H}_{2} \mathrm{O}_{2}$ levels by stimulating the catalytic activity of catalase [16]. In this study, we found that the acceleration of $\mathrm{NaCl}$ on SOD, APX and CAT in B. gymnorrhiza leaves was reduced by $\mathrm{CaM}$ inhibitor, TFP (Fig. 6), indicating that SOD and POD in $B$. gymnorrhiza were presumably up-regulated by CaM isoforms since plants possess a number of CaM isoforms that exhibit differential activation of CaM-dependent enzymes in vitro [55].

\section{CONCLUSION}

Our data show that ABA and CaM levels in $B$. gymnorrhiza and $K$. candel increased upon a ST and a LT salt treatment. $\mathrm{NaCl}$-induced $\mathrm{ABA}$ and $\mathrm{CaM}$ seem to contribute ionic and ROS (reactive oxygen species) homeostasis control in the two species. ABA and CaM likely restricted root-to-shoot salt transport by reducing water flow. Moreover, ABA and CaM may up-regulate the activity of antioxidant enzymes in the two mangrove species, thus avoids excess ROS production and the subsequent oxidative stress. Therefore, leaf MDA and MP did not significantly increase although LT salinity caused a buildup of $\mathrm{Na}^{+}$and $\mathrm{Cl}^{-}$in leaves of the two mangrove species.

\section{ACKNOWLEDGEMENTS}

The research was supported jointly by the National Natural Science Foundation of China (30430430, 30872005), the HI-TECH Research and Development Program of China (863 Program, 2006AA10Z131), the Alexander von Humboldt-Stiftung/Foundation (Germany), Foundation for the Supervisors of Beijing Excellent Doctoral Dissertation (YB20081002201), Foundation for the Authors of National Excellent Doctoral Dissertation of PR China (200152), the Teaching and Research Award Program for Outstanding Young Teachers in Higher Education Institution of Ministry of Education (MOE), PRC (2002-323), Key project of MOE (2009-84), the Natural Science Foundation of Hubei province (2007ABB003) and Natural Science Foundation of Hainan Province (30408). We thank Professor Juan Bai (Hebei Normal University, Shijiazhuang, China) for valuable suggestions with regard to CaM assay. Professor Bao-Min Wang (China Agricultural University, Beijing, China) is acknowledged for his technical assistance with the ABA analysis.

\section{REFERENCES}

[1] Sreenivasulu N, Grimm B, Wobus U, Weschke W. Differential response of antioxidant compounds to salinity stress in salt-tolerant and salt-sensitive seedlings of foxtail millet (Setaria italica). Physiol Plant 2000; 109: 435-42.

[2] Mittova V, Guy M, Tal M, Volokita M. Salinity up-regulates the antioxidative system in root mitochondria and peroxisomes of the wild salt-tolerant tomato species Lycopersicon pennellii. J Exp Bot 2004; 55: 1105-13

[3] Parida A, Das AB, Mohanty P. Defense potentials to $\mathrm{NaCl}$ in a mangrove, Bruguiera parviflora: differential changes of isoforms of some antioxidative enzymes. J Plant Physiol 2004; 161: 531-42. 
[4] Gossett DG, Millhollon EP, Lucas MC. Antioxidant response to $\mathrm{NaCl}$ stress in salt tolerant and sensitive cultivars of cotton. Crop Sci 1994; 34: 706-14.

[5] Dionisio-Sese ML, Tobita S. Antioxidant responses of rice seedlings to salinity stress. Plant Sci 1998; 135: 1-9.

[6] Hernández JA, Ferrer MA, Jiménez A, Barcelo AR, Sevilla F. Antioxidant systems and $\mathrm{O}_{2}{ }^{-} / \mathrm{H}_{2} \mathrm{O}_{2}$ production in the apoplast of pea leaves. Its relation with salt-induced necrotic lesions in minor veins. Plant Physiol 2001; 127: 817-31.

[7] Wang $\mathrm{R}$, Chen $\mathrm{S}$, Ma $\mathrm{H}$, et al. Genotypic difference in antioxidative stress and salt tolerance of three poplars under salt stress. Front For China 2006; 1: 82-8.

[8] Wang R, Chen S, Deng L, Fritz E, Hüttermann A, Polle A. Leaf photosynthesis, fluorescence response to salinity and the relevance to chloroplast salt compartmentation and antioxidative stress in two poplars. Trees 2007; 21: 581-91.

[9] Zhao K, Munns R, King RW. Abscisic acid synthesis in NaCltreated barley, cotton and saltbush. Aust J Plant Physiol 1991; 18: $17-24$

[10] Montero E, Cabot C, Barceló J, Poschenrieder C. Endogenous abscisic acid levels are linked to decreased growth of bush bean plants treated with NaCl. Physiol Plant 1997; 101: 17-22.

[11] Gómez-Cadenas A, Tadeo FR, Primo-Millo E, Talon M. Involvement of abscisic acid and ethylene in the responses of citrus of seedlings to salt shock. Physiol Plant 1998; 103: 475-84.

[12] Guan L, Scandalios JG. Two structurally similar maize cytosolic superoxide dismutase genes, Sod4 and Sod4A, respond differentially to abscisic acid and high osmoticum. Plant Physiol 1998; 117: 217-24.

[13] Chen S, Li J, Wang T, Wang S, Polle A, Hüttermann A. Osmotic stress and ion-specific effects on xylem abscisic acid and the relevance to salinity tolerance in poplar. J Plant Growth Regul 2002; 21: 224-33

[14] Chen S, Li J, Wang T, Wang S, Polle A, Hüttermann A. Gas exchange, xylem ions and abscisic acid response to $\mathrm{Na}^{+}$-salts and $\mathrm{Cl}^{-}$-salts in Populus euphratica. Acta Bot Sin 2003; 45: 561-6.

[15] Yoo JH, Park CY, Kim JC, et al. Direct interaction of a divergent $\mathrm{CaM}$ isoform and the transcription factor, MYB2, enhances salt tolerance in Arabidopsis. J Biol Chem 2005; 280: 3697-706.

[16] Yang T, Poovaiah BW. Hydrogen peroxide homeostasis: activation of plant catalase by calcium/calmodulin. Proc Natl Acad Sci USA 2002; 99: 4097-102

[17] Tomlinson PB. The botany of mangroves. Cambridge: Cambridge University Press 1986

[18] Lüttge U. Physiological ecology of tropical plants. Berlin: Springer-Verlag; 1997.

[19] Takemura T, Hanagata N, Dubinsky Z, Karube I. Molecular characterization and response to salt stress of mRNAs encoding cytosolic $\mathrm{Cu} / \mathrm{Zn}$ superoxide dismutase and catalase from Bruguiera gymnorrhiza. Trees 2002; 16: 94-9.

[20] Zhou BY, Guo ZF. Effects of abscisic acid and abscisic acid biosynthesis inhibitor to the cold resistance and antioxidant enzymes activity in Stylosanthes guianensis. Acta Pratacul Turae Sinica 2005; 14: 94-9.

[21] Heath RL, Packer L. Photoperoxidation in isolated chloroplasts. I. Kinetics and stoichiometry of fatty acid peroxidation. Arch Biochem Biophys 1968; 125: 189-98.

[22] Chen S, Li J, Wang S, Hüttermann A, Altman A. Salt, nutrient uptake and transport, and ABA of Populus euphratica; a hybrid in response to increasing soil $\mathrm{NaCl}$. Trees 2001; 15: 186-94.

[23] Wu SR, Chen WF, Zhou X. Solid phase enzyme-linked immunosorbent assays (ELISA) determine endogenous plant hormones. Plant Physiol Commun 1988; 5: 53-7 (in Chinese).

[24] Zhao SH, Yu HL, Zhang MZ. Enzyme-linked immunosorbent assays (ELISA) for calmodulin. Acta Acad Med Xuzhou 1988; 8: 54-8 (in Chinese).

[25] Giannopolits CN, Ries SK. Superoxide dismutases occurrence in higher plants. Plant Physiol 1977; 59: 309-14.

[26] Kochba J, Lavce S, Spiegel RP. Difference in peroxidase activity and isoenzymes in embryogenic orange ovular callus lines. Plant Cell Physiol 1977; 18: 463-7.
[27] Mishra NP, Mishra PK, Singhal GS. Changes in the activities of antioxidant enzymes during exposure of intact wheat leaves to strong visible light at different temperatures in the presence of protein synthesis inhibitors. Plant Physiol 1993; 102: 903-10.

[28] Miyagawa Y, Tamori M, Shigeoka S. Evaluation of the defense system in chloroplasts to photooxidative stress caused by paraquat using transgenic tobacco plants expressing catalase from Escherichia coli. Plant Cell Physiol 2000; 41: 311-20.

[29] Schaedle M, Bassham JA. Chloroplast glutathione reductase. Plant Physiol 1977; 59: 1011-2.

[30] Hernández JA, Corpas FJ, Gomez M, del Rio LA, Sevilla F. Saltinduced oxidative stress mediated by activated oxygen species in pea leaf mitochondria. Physiol Plant 1993; 89: 103-10.

[31] Hernández JA, Olmo E, Corpas FJ, Sevilla F, del Rio LA. Saltinduced oxidative stress in chloroplast of pea plants. Plant Sci 1995; 105: 151-67.

[32] Hernández JA, Campillo A, Jiménez A, Alarcon JJ, Sevilla F. Response of antioxidant systems and leaf water relations to $\mathrm{NaCl}$ stress in pea plants. New Phytol 1999; 141: 241-51.

[33] Hernández JA, Jiménez A, Mullineaux P, Sevilla F. Tolerance of pea (Pisum sativum L.) to long-term salt stress is associated with induction of antioxidant defenses. Plant Cell Environ 2000; 23 : 853-62.

[34] Gosset DR, Banks SW, Millhollon EP, Lucas MC. Antioxidant response to $\mathrm{NaCl}$ stress in a control and an $\mathrm{NaCl}$-tolerant cotton cell line grown in the presence of paraquat, buthionine sulfoximine, and exogenous glutathione. Plant Physiol 1996; 112: 803-9.

[35] Gómez JM, Hernández JA, Jiménez A, del Río LA, Sevilla F. Differential response of antioxidative enzymes of chloroplasts and mitochondria to long-term $\mathrm{NaCl}$ stress of pea plants. Free Rad Res 1999; 31: S11-S8.

[36] Savouré A, Thorin D, Davey $\mathrm{M}$, et al. $\mathrm{NaCl}$ and $\mathrm{CuSO}_{4}$ treatments trigger distinct oxidative defense mechanism in Nicotiana plumbaginifolia L. Plant Cell Environ 1999; 22: 387-96.

[37] Asada K, Takahashi M. In: Kyle DJ, Osmond CB, Arntzen CJ, Eds. Photoinhibition. Amsterdam: Elsevier Science Publishers 1987; pp. 227-87.

[38] Ruth GA, Neval E, Lenwood SH. Role of superoxide dismutases in controlling oxidative stress in plants. J Exp Bot 2002; 53: 1331-41.

[39] Beauchamp CO, Fridovich I. Isoenzymes of superoxide dismutase from wheat germ. Biochem Biophys Acta 1973; 317: 50-64.

[40] Prasad TK, Anderson MD, Martin BA, Stewart CR. Evidence for chilling-induced oxidative stress in maize seedlings and a regulatory role for hydrogen peroxide. Plant Cell 1994; 6: 65-74.

[41] Desikan R, Mackerness S, Hancock JT, Neill SJ. Regulation of the Arabidopsis transcriptome by oxidative stress. Plant Physiol 2001; 127: 159-72.

[42] Vranová E, Inzé D, Breusegem F. Signal transduction during oxidative stress. J Exp Bot 2002; 53: 1227-36

[43] Foyer $\mathrm{CH}$, Mullineaux PM. Causes of photooxidative stress and amelioration of defense systems in plants. Boca Raton, Ann Arbor, London, Tokyo: CRC Press 1994.

[44] Halliwell B, Gutteridge JMC. Free radicals in biology and medicine. London: Oxford University Press 1989.

[45] Karmoker JL, Van Steveninck RFM. The effect of abscisic acid on the uptake and distribution of ions in intact seedlings of Phaseolus vulgaris cv. Redland Pioneer. Physiol Plant 1979; 45: 453-9.

[46] Xiong L, Gong Z, Rock CD, et al. Modulation of abscisic acid signal transduction and biosynthesis by an Sm-like protein in Arabidopsis. Dev Cell 2001; 1: 771-81.

[47] Zhu JK. Salt and drought stress signal transduction in plants. Ann Rev Plant Biol 2002; 53: 247-73.

[48] Little CHA, Eidt DC. Effects of abscisic acid on budbreak and transpiration in woody species. Nature 1968; 220: 498-9.

[49] Mittelheuser CJ, Van Steveninck RFM. Stomatal closure and inhibition of transpiration induced by (RS)-abscisic acid. Nature 1969; 221: 281-2.

[50] Chang Y, Chen S, Yin W, et al. Growth, gas exchange, abscisic acid, and calmodulin response to salt stress in three poplars. J Integr Plant Biol 2006; 48: 286-93. 
[51] Zhang Y, Shi Y, Wang R, et al. Effects of ABA and CaM on leaf gas exchange of Populus euphratica in the process of initial salinity. Scientia Silvae Sinicae 2008; 44: 57-64 (in Chinese with English abstract).

[52] Chen S, Li J, Fritz E, Wang S, Hüttermann A. Sodium and chloride distribution in roots and transport in three poplar genotypes under increasing $\mathrm{NaCl}$ stress. For Ecol Manage 2002; 168: 217-30.

[53] Chen S, Li J, Wang S, Fritz E, Hüttermann A, Altman A. Effects of $\mathrm{NaCl}$ on shoot growth, transpiration, ion compartmentation and transport in regenerated plants of Populus euphratica and Populus tomentosa. Can J For Res 2003; 33: 967-75.

[54] Jiang M, Zhang J. Abscisic acid and antioxidant defense in plant cells. Acta Botanica Sinica 2004; 46: 1-9.

[55] Lee SH, Johnson JD, Walsh MP, et al. Differential regulation of $\mathrm{Ca}^{2+} /$ calmodulin-dependent enzymes by plant calmodulin isoforms and free $\mathrm{Ca}^{2+}$ concentration. Biochem J 2000; 350: 299-306.

Received: December 15, 2007

Revised: March 25, 2009

Accepted: September 28, 2009

(C) Li et al.; Licensee Bentham Open.

This is an open access article licensed under the terms of the Creative Commons Attribution Non-Commercial License (http://creativecommons.org/licenses/bync/3.0/) which permits unrestricted, non-commercial use, distribution and reproduction in any medium, provided the work is properly cited. 